\title{
PREPARATION AND THERMAL STABILITY OF ULTRA-FINE AND NANO-GRAINED COMMERCIALLY PURE TITANIUM WIRES USING CONFORM EQUIPMENT
}

\author{
PRIPRAVA KOMERCIALNE ULTRADROBNE IN NANOZRNATE \\ Ti-ŽICE Z OPREMO CONFORM IN NJENA TERMIČNA \\ STABILNOST
}

\author{
Tomáš Kubina1, Jaromír Dlouhý1, Michal Köver¹, Mária Dománková², \\ Josef Hodek ${ }^{1}$ \\ ${ }^{1}$ COMTES FHT, Prumyslova 995, 33441 Dobrany, Czech Republic \\ 2Institute of Materials Science, Faculty of Materials Science and Technology in Trnava, STU in Bratislava, Bottova 25,91724 Trnava, \\ Slovakia \\ tomas.kubina@comtesfht.cz \\ Prejem rokopisa - received: 2013-10-03; sprejem za objavo - accepted for publication: 2014-04-01
}

doi: $10.17222 /$ mit.2013.226

Processes based on severe plastic deformation (SPD) capable of producing microstructures with sizes of the order of nanometres are gaining increasing importance. One of the available ways to make production more efficient is to combine the CONFORM continuous extrusion process with the ECAP method. This paper describes our initial experience with this combined process in a CONFORM $315 \mathrm{i}$ machine, equipped with a specially designed die chamber. Trials were performed to explore the impact of the CONFORM equipment's settings on the microstructure of the Ti wire. The feedstock consisted of CP-Ti grade 2 bar with a diameter of $10 \mathrm{~mm}$. The decisive parameter for the entire process, i.e., the die-chamber temperature, was varied and controlled. Specimens with grain sizes of $1.4 \mu \mathrm{m}$ and $420 \mathrm{~nm}$ were obtained. Using these specimens, the temperatures at which the recovery processes began to take effect were determined by thermal analysis.

Keywords: CONFORM-ECAP, titanium wire, ultrafine microstructure, nanostructure, thermal stability

Postopki, ki temeljijo na veliki plastični deformaciji (SPD), pri katerih nastaja mikrostruktura z nanometrskimi dimenzijami, pridobivajo na pomenu. Ena od mogočih poti za bolj učinkovito proizvodnjo je kombinacija kontinuirnega postopka ekstruzije CONFORM in metode ECAP. Ta članek opisuje začetne izkušnje s tem kombiniranim postopkom z napravo CONFORM 315i, opremljeno s posebno oblikovano komoro. Preizkusi so bili opravljeni zato, da bi ugotovili vpliv nastavitve naprave CONFORM na mikrostrukturo Ti-žice. Vložek je bila palica CP-Titan 2 premera $10 \mathrm{~mm}$. Spreminjana in kontrolirana je bila temperatura komore kot ključni parameter celotnega postopka. Dobljeni so bili vzorci z velikostjo zrn 1,4 $\mu \mathrm{m}$ in $420 \mathrm{~nm}$. Pri teh vzorcih je bila s termično analizo določena temperatura, pri kateri se začne proces poprave.

Ključne besede: CONFORM-ECAP, žica iz titana, ultradrobna mikrostruktura, nanostruktura, termična stabilnost

\section{INTRODUCTION}

In the past 15 years, numerous SPD processes (Severe Plastic Deformation) have been developed. These processes are used for achieving grain refinement in materials, typically to a grain size between $100 \mathrm{~nm}$ and $400 \mathrm{~nm}$. Their efficiency in processing a large volume of material is, however, still insufficient for industrial-scale applications. This drawback has now been overcome by the CONFORM method, which is known for a long time and is used for the continuous, industrial-scale production of sections, mostly from aluminium. By merging two processes, where the feedstock is forced through a die by the friction force of a wheel, ECAP becomes a continuous process ${ }^{1,2}$. The first results of limited-scope process experiments conducted by COMTES FHT were presented $\mathrm{in}^{3}$. The ultrafine titanium obtained was annealed isothermally to explore the growth of the mean grain size. In this case, the grain-growth kinetics can be described as grain coarsening from the very beginning of the annealing process. The isothermal grain coarsening is described with the equation:

$$
d^{1 / n}-d_{0}^{1 / n}=t K_{0} \exp \left(-\frac{Q}{R T}\right)
$$

where $d$ is the mean grain size at the annealing time $t, T$ is the temperature, $n$ is the time exponent, $d_{0}$ is the initial grain size, $K_{0}$ is a constant, $R$ is the universal gas constant and $Q$ is the grain-growth activation energy. Equation (1) was used for expressing the distorted grain-growth rate in CP-Ti in terms of the time exponent $(n)$ and the activation energy $(Q)$. The scatter in the measured mean grain size also caused problems in finding the activation energy $Q$. Its value was determined using graphical methods: $248 \mathrm{~kJ} \mathrm{~mol}^{-1}$ (at the mean $n=0.19)^{4}$. This value is substantially higher than the activation energy of $\mathrm{Ti}$ self-diffusion (169.1 $\left.\mathrm{kJ} \mathrm{mol}^{-1}\right)^{5}$ and the grain-growth activation energy in CP-Ti after eight ECAP passes $\left(176 \mathrm{~kJ} \mathrm{~mol}^{-1}\right)^{6}$. 
This paper expands the knowledge of the production of nanostructured titanium and describes its thermal stability by thermo-physical tests with a contrast to the stability of an ultrafine-grained variant.

\section{EXPERIMENTAL}

The feedstock consisted of CP-Ti grade 2 bar with a diameter of $10 \mathrm{~mm}$. The chemical composition of the feedstock is shown in Table 1. It was measured using a Bruker Q4 Tasman optical emission spectrometer and a Bruker G8 Galileo gas analyser.

Table 1: Chemical composition of feedstock in mass fractions, $w / \%$ Tabela 1: Kemijska sestava uporabljenega materiala v masnih deležih, $w / \%$

\begin{tabular}{|c|c|c|c|c|c|}
\hline $\mathrm{Fe}$ & $\mathrm{O}$ & $\mathrm{C}$ & $\mathrm{H}$ & $\mathrm{N}$ & $\mathrm{Ti}$ \\
\hline 0.046 & 0.12 & 0.023 & 0.0026 & 0.0076 & 99.822 \\
\hline
\end{tabular}

Titanium bars were converted into an "endless" bar of the same diameter as the feedstock using the CONFORM 315i machine. The material's mechanical properties at room temperature were determined with cylindrical tensile test specimens with a gauge length of $25 \mathrm{~mm}$ and a diameter of $5 \mathrm{~mm}$. In addition, V-notch impact tests were conducted using specimens with a $3 \mathrm{~mm} \times 4 \mathrm{~mm}$ cross-section. Two processing experiments were conducted with different sets of extrusion parameters.

The microstructures of the specimens were observed in a JEOL JSM 7400 FEG scanning electron microscope with a field-emission gun and with a Nordlys (Oxford Instruments) EBSD (Electron Backscatter Diffraction) detector. The specimens for the EBSD analysis were prepared by ion polishing in a JEOL SM-09010 Cross Section Polisher. The EBSD observation conditions were as follows: $25 \mathrm{kV}$ voltage, working distance of $15.5 \mathrm{~mm}$, 500 point $\times 500$ point lattice and a step size of $0.1 \mu \mathrm{m}$. The EBSD maps were displayed and edited using HKL Channel 5 software. The intercept grain size was assessed by measuring the lengths between points of intersection between grain boundaries and a square grid, according to the Czech Standard ČSN EN ISO 643.

For the purposes of observation in the transmission electron microscope (TEM), thin foils were prepared with final electrolytic thinning in a Tenupol 5 device, using a solution of $300 \mathrm{~mL} \mathrm{CH}_{3} \mathrm{OH}+175 \mathrm{~mL}$ 2-butanol $+30 \mathrm{~mL} \mathrm{HClO}_{4}$ at $-10{ }^{\circ} \mathrm{C}$ and a voltage of $40 \mathrm{~V}$. The TEM analysis was performed in a JEOL 200CX instrument with an acceleration voltage of $200 \mathrm{kV}$. Selective electron diffraction was used for the determination of the phases.

The effect of deformation on the thermal expansion of titanium and the temperature range for recovery were explored using a Linseis L75 Platinum horizontal dilatometer with an $\mathrm{Al}_{2} \mathrm{O}_{3}$ specimen chamber and a pull bar. The temperature changes were monitored with a thermo- couple on specimens of diameter $5 \mathrm{~mm}$ and lengths of approximately $20 \mathrm{~mm}$. Nitrogen $\left(\mathrm{N}_{2}\right)$ was used as the protective gas. After heating to $950{ }^{\circ} \mathrm{C}$ at a rate of $3 \mathrm{~K} / \mathrm{min}$ the specimen was cooled at $20 \mathrm{~K} / \mathrm{min}$ to $600{ }^{\circ} \mathrm{C}$. Then the specimen was left to cool in air to the ambient temperature. The recovery processes were monitored in a Linseis PT-1600 heat-flux calorimeter equipped with an S-type thermocouple. The measurement was conducted in $\mathrm{Ar}$ at a flow rate of $600 \mathrm{~mL} / \mathrm{min}$ on specimens with a mass of approximately $41 \mathrm{mg}$, cut off from diameter bars $5 \mathrm{~mm}$ and placed in $\mathrm{Al}_{2} \mathrm{O}_{3}$ crucibles with lids.

\section{MICROSTRUCTURE AFTER EXPERIMENTAL PROCESSING}

The feedstock microstructure contained equiaxed grains with scarce twins (Figure 1). After the deformation it consisted of two types: recrystallized equiaxed grains and a small proportion (less than $15 \%$ ) of distorted grains divided into sub-grains by low-angle boundaries. The as-received and distorted microstructures exhibited an identical pronounced texture with (1000) planes aligned with the specimen axis. The experimental extrusion was based on varying the key parameters: the speed of the wheel, the die-chamber temperatures and the cooling downstream of the die chamber. The process-controlling parameter was the die-chamber temperature, and it was varied from an initial $500{ }^{\circ} \mathrm{C}$ to a final $350{ }^{\circ} \mathrm{C}$. The specimens represent runs at various diechamber temperatures. The microstructure of the specimen processed in the die chamber at a temperature of $500{ }^{\circ} \mathrm{C}$ consisted of recrystallized equiaxed grains with a bimodal size with an average size of $1.9 \mu \mathrm{m}$. Neither the small nor the large grains exhibit distorted structures. The die-chamber temperature of $450{ }^{\circ} \mathrm{C}$ is sufficient for the microstructure to recover/recrystallize. No effects of the cooling were detected. The recovery/recrystallization and potential grain growth finished before the specimen was cooled. The specimen pro-

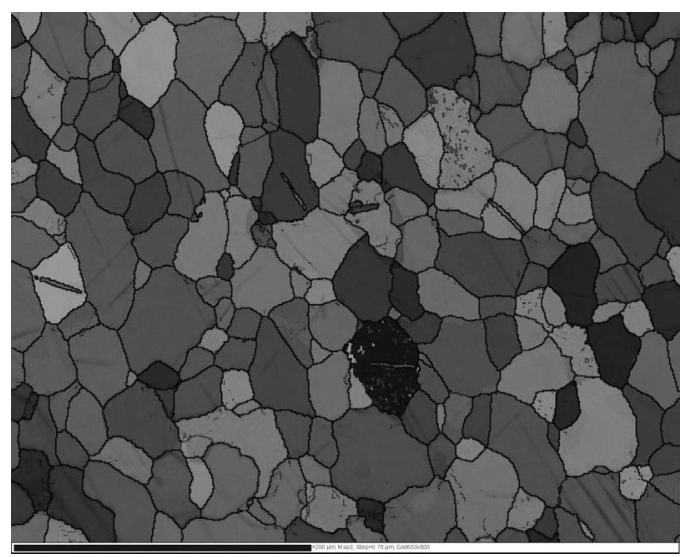

Figure 1: Microstructural state of the feedstock material (length of scale $200 \mu \mathrm{m})$

Slika 1: Stanje mikrostrukture izhodnega materiala (dolžina skale je $200 \mu \mathrm{m})$ 
Table 2: Mechanical properties and average grain size for various states of CP-Ti Tabela 2: Mehanske lastnosti in povprečna velikost zrn pri različnih stanjih CP-Ti

\begin{tabular}{|c|c|c|c|c|c|c|c|}
\hline & $\begin{array}{c}\text { Proof stress } \\
R_{\mathrm{p} 0.2} / \mathrm{MPa}\end{array}$ & $\begin{array}{c}\mathrm{UTS} \\
R_{\mathrm{m}} / \mathrm{MPa}\end{array}$ & $A_{\mathrm{g}} / \%$ & $A_{5} / \%$ & $Z / \%$ & $K C V /\left(\mathrm{J} \mathrm{cm}^{-2}\right)$ & $d / \mu \mathrm{m}$ \\
\hline Feedstock & 354 & 470 & 9.3 & 32.3 & 64.2 & 64.2 & 5.39 \\
\hline Single pass $\left(350^{\circ} \mathrm{C}\right)$ & 620 & 694 & 12.0 & 26.3 & 55.7 & 27.5 & 1.4 \\
\hline Three passes $\left(200{ }^{\circ} \mathrm{C}\right)$ & 637 & 698 & 1.77 & 17.8 & 66.2 & - & 0.42 \\
\hline
\end{tabular}

cessed at the die chamber temperature of $400{ }^{\circ} \mathrm{C}$ began to show changes as it contained a small amount $(10-15 \%)$ of deformed, un-recrystallized grains. Distorted grains with a size of no more than $5 \mu \mathrm{m} \times 10 \mu \mathrm{m}$ were divided by low-angle boundaries into sub-grains. The average grain size was $1.9 \mu \mathrm{m}$.

Figure 2 shows the microstructure upon water cooling after the processing at a chamber temperature of $350{ }^{\circ} \mathrm{C}$, consisting of slightly elongated, deformed grains. The EBSD analysis was focused on the centre of the circular cross-section of the extruded product. The analysed surface is in a plane that is parallel to the bending plane/flow plane in the CONFORM chamber. On the EBSD maps the axis of the extruded section is vertical and the specimen grain size was $1.4 \mu \mathrm{m}$. The titanium wire processed in this way was then used for the annealing experiment. The mechanical properties of the feedstock and of the Ti wire after a single pass at the die chamber temperature of $350{ }^{\circ} \mathrm{C}$ are listed in Table 2 . As expected, the yield stress and the ultimate strength of the product are higher than those of the feedstock. On the other hand, its contraction, elongation and the impact toughness upon the first pass are lower than those of the feedstock.

In the second processing experiment, the feedstock preheating device of the CONFORM machine was turned off, the chamber temperature was set to $200{ }^{\circ} \mathrm{C}$ and the wheel speed was $0.5 \mathrm{~m} \mathrm{~s}^{-1}$. In this experiment, three CONFORM passes of Ti wire were used. As the amount of strain introduced into the material was sub-

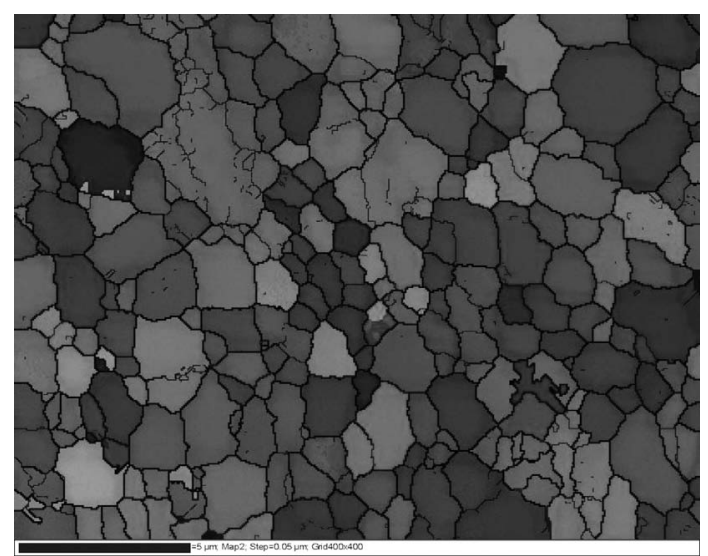

Figure 2: Microstructural state of CP-Ti subjected to one pass through the CONFORM machine at $350{ }^{\circ} \mathrm{C}$ (length of scale $200 \mu \mathrm{m}$ )

Slika 2: Stanje mikrostrukture CP-Ti po 1 prehodu skozi napravo CONFORM pri $350{ }^{\circ} \mathrm{C}$ (dolžina skale je $200 \mu \mathrm{m}$ ) stantial, the EBSD examination did not give any result. All three specimens were also examined using the TEM.

\subsection{TEM analysis of the microstructure}

From samples of Ti wire upon each pass, foils for the transmission electron microscopy observations, oriented in longitudinal and transverse directions, were prepared and in this work the results of the examination of the longitudinal cross-sections are presented. In this direction, the change in grain size with the introduced strain was critically assessed.

Upon the first CONFORM pass with a chamber temperature of $200{ }^{\circ} \mathrm{C}$, the microstructure on the longitudinal section consisted of polyhedral grains with an elevated dislocation density, distorted grains and even disc-shaped grains, as shown in Figure 3.

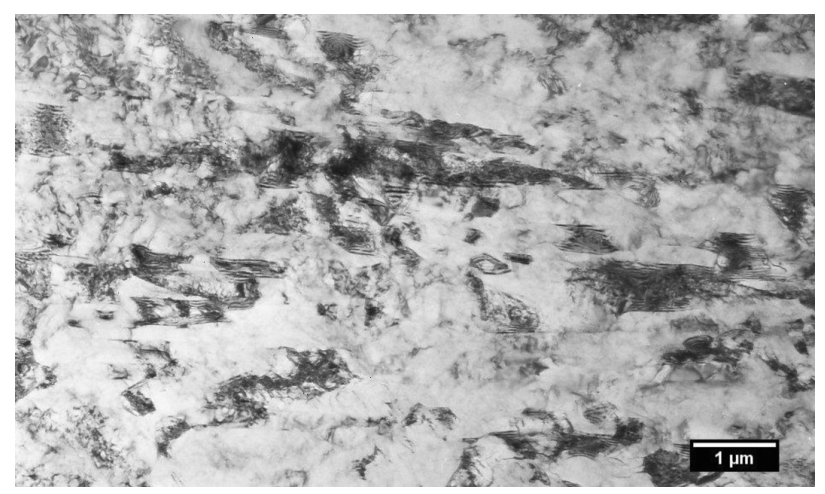

Figure 3: Region with grains with deformation texture within Ti wire after the first pass at $200{ }^{\circ} \mathrm{C}$

Slika 3: Področje z zrni z deformacijsko teksturo v Ti-žici po prvem prehodu pri $200{ }^{\circ} \mathrm{C}$

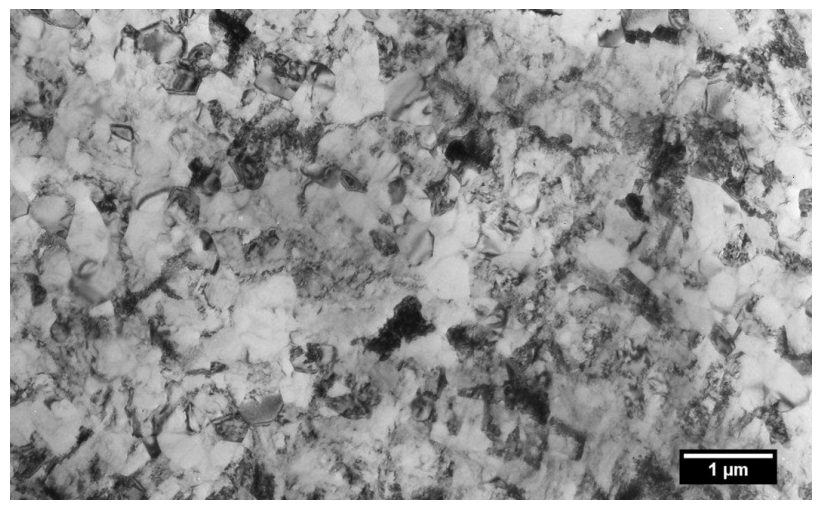

Figure 4: General view of Ti wire substructure after second pass at $200{ }^{\circ} \mathrm{C}$

Slika 4: Videz podstrukture v Ti-žici po drugem prehodu pri $200{ }^{\circ} \mathrm{C}$ 


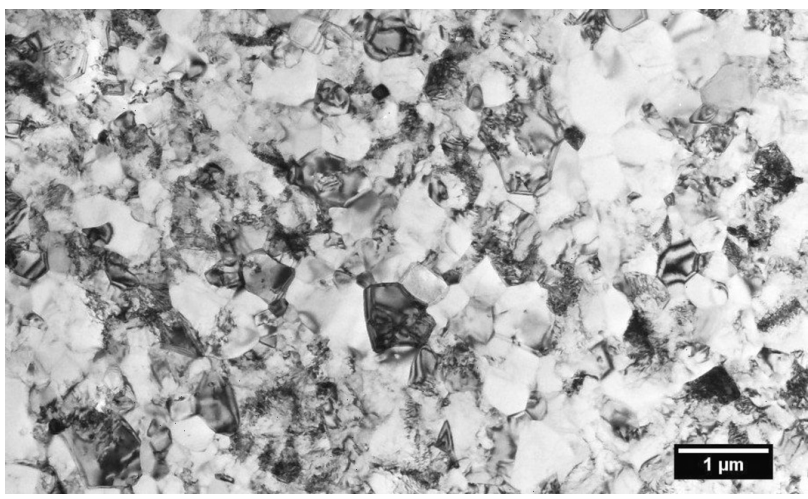

Figure 5: General view of Ti wire substructure after third pass at 200 ${ }^{\circ} \mathrm{C}$

Slika 5: Videz podstrukture v Ti-žici po tretjem prehodu pri $200{ }^{\circ} \mathrm{C}$

The nature of the substructure of the samples taken upon the second pass is similar to the condition seen on the transverse cross-section and the very fine-grained polyhedral microstructure is shown in Figure 4. The grain size measured was $d_{\text {str }} \approx(310 \pm 30) \mathrm{nm}$, with a difference compared to the previous specimen. On the longitudinal section there were areas of distorted grains or grains with a disc morphology, while the previous specimen contained no such grains.

Figure 5 characterizes the substructure of the specimens on the longitudinal section through the wire upon three CONFORM passes. The nature of the substructure is very similar to that on the transverse cross-section. The grains are polygonal, with a mean size of $d_{\text {str }} \approx(420$ $\pm 30) \mathrm{nm}$. On this section too, areas can be found where the dislocation density is low, but locations with a higher dislocation density are present as well.

\section{RESULTS OF THE THERMAL ANALYSIS}

The results of the dilatometer measurement were processed with Linseis Data Evaluation software (Figure 6). The specimen after one pass through the CONFORM

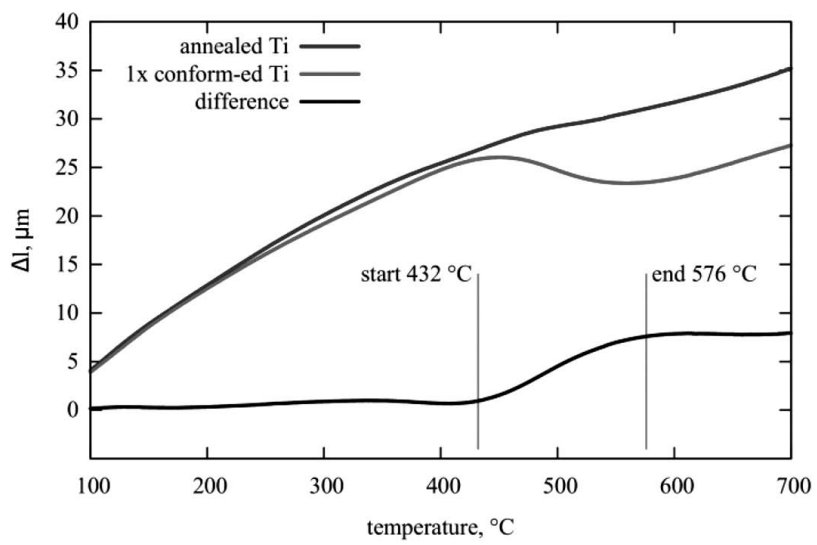

Figure 6: Dependence of the change in length on the temperature for different states of $\mathrm{CP}$-Ti processed at $350{ }^{\circ} \mathrm{C}$

Slika 6: Odvisnost spremembe dolžine od temperature za različna stanja $\mathrm{CP}-\mathrm{Ti}$, predelanega pri $350{ }^{\circ} \mathrm{C}$

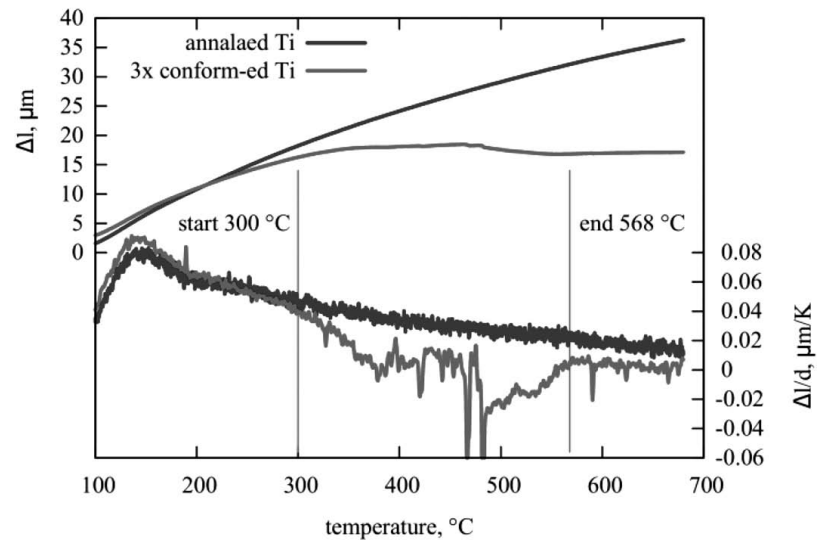

Figure 7: Dependence of the change of length on the temperature for different states of CP-Ti processed at $200{ }^{\circ} \mathrm{C}$

Slika 7: Odvisnost spremembe dolžine od temperature za različna stanja $\mathrm{CP}-\mathrm{Ti}$, predelanega pri $200{ }^{\circ} \mathrm{C}$

machine at $350{ }^{\circ} \mathrm{C}$ showed a reduced elongation, which can be explained by the annihilation of dislocations and the elimination of the lattice stress. This was not observed in the annealed feedstock, which received no deformation and so eventual effects of the phase transformation can be ruled out. The calculated difference between the changes in the lengths of the feedstock and the processed specimen suggest that in the temperature range $432-576{ }^{\circ} \mathrm{C}$ the recovery caused a substantial change in the length.

The same method was used for measuring the variation in the thermal expansion for the specimen upon three passes at $200{ }^{\circ} \mathrm{C}$. The lower limit of the interval of the initial recovery of deformed $\mathrm{Ti}$ wire is shifted towards notably lower temperatures, to $300-560{ }^{\circ} \mathrm{C}$, according to Figure 7.

The results of the differential scanning calorimeter (DSC) measurement on a specimen after a single pass at $350{ }^{\circ} \mathrm{C}$ are shown in Figure 8. Above $300{ }^{\circ} \mathrm{C}$, the temperature increase in both specimens is in accordance with the thermal schedule (constant heating rate of

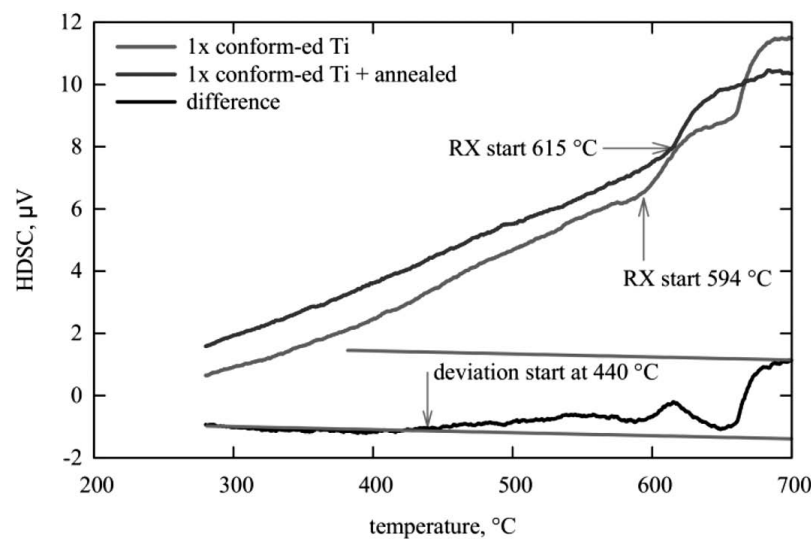

Figure 8: Heat flux vs. temperature dependence in a specimen after a single pass at $350{ }^{\circ} \mathrm{C}$

Slika 8: Odvisnost toplotnega toka od temperature v vzorcu po enem prehodu pri $350{ }^{\circ} \mathrm{C}$ 


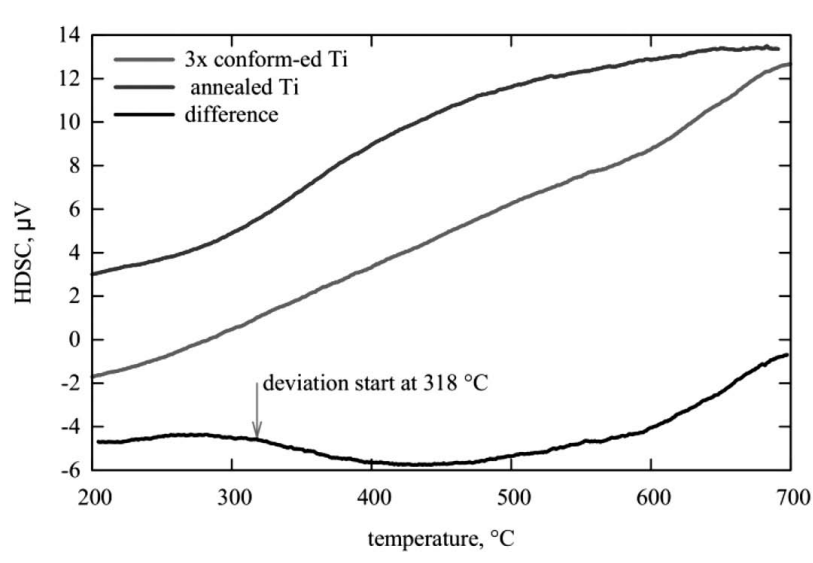

Figure 9: Heat flux vs. temperature dependence in a specimen after three passes at $200{ }^{\circ} \mathrm{C}$

Slika 9: Odvisnost toplotnega toka od temperature v vzorcu po treh prehodih pri $200{ }^{\circ} \mathrm{C}$

$10 \mathrm{~K} / \mathrm{min}$ ). Despite that, the curves for both specimens (the processed one and the one annealed in the DSC) show differences. As the calculation shows, there is a steeper increase in the stress in the processed specimen at temperatures above $440{ }^{\circ} \mathrm{C}$ (Figure 8). Apparently, an exothermic reaction, generating heat, takes place. This region matches the recovery zone identified in the dilatometric measurement. (The higher onset temperature found in the DSC may be due to the higher heating rate, the larger specimen, and the resulting response). It may be attributed to the release of heat by recovery stress relaxation. In the processed specimens, the recrystallization peak was detected at lower temperatures, in accordance with the theoretical and empirical knowledge of the dependence of recrystallization on the temperature and the strain. In the specimen processed with three passes through the CONFORM machine at $200{ }^{\circ} \mathrm{C}$, the DSC method showed a more notable decrease in the temperature for the onset of the exothermic reaction, being approximately $320^{\circ} \mathrm{C}$, as shown in Figure 9 .

The recrystallization temperature in the undeformed specimen was $T_{\mathrm{rx}}=615^{\circ} \mathrm{C}$, and $594^{\circ} \mathrm{C}$ for a single-pass "conformed" specimen. The decrease in the recrystallization temperature down to $527^{\circ} \mathrm{C}$ in a $\mathrm{CP}-\mathrm{Ti}$ specimen after eight ECAP passes has been reported in 7 .

\section{CONCLUSION}

The effect of CONFORM straining on the microstructure of a $\mathrm{Ti}$ wire was investigated. It was found that the die-chamber temperature had the strongest influence. The smallest mean grain size found by EBSD was $1.4 \mu \mathrm{m}$, which was achieved at a die-chamber temperature of $350{ }^{\circ} \mathrm{C}$. The microstructure of the processed material after three passes at a die chamber temperature of $200{ }^{\circ} \mathrm{C}$ was examined. After the first pass, the microstructure contained a notable number of slip bands, and after the second and third passes, the character of microstructure was identical, with fine polyhedral grains with low and high dislocation densities. After the third CONFORM pass, the mean grain size of $d_{s \mathrm{tr}} \approx(420 \pm 30) \mathrm{nm}$ was obtained. The thermal analysis showed that the increasing amount of strain introduced temperatures for the onset of the recovery decrease. In the Ti wire with the mean grain size of $1.4 \mu \mathrm{m}$, the recovery began at approximately $440{ }^{\circ} \mathrm{C}$, and for the Ti wire with the grain size of $420 \mathrm{~nm}$, this temperature is even lower, i.e., 310 ${ }^{\circ} \mathrm{C}$. As polyhedral grains with varying dislocation densities are present, is becomes clear that the recovery phenomena take place even during the forming process. It also suggests that the forming temperature is lower than the recorded die-chamber temperature.

\section{REFERENCES}

${ }^{1}$ G. J. Raab, R. Z. Valiev, T. C. Lowe, Y. T. Zhu, Continuous processing of ultrafine grained Al by ECAP-Conform, Materials Science and Engineering: A, 382 (2004) 1/2, 30-34, doi:10.1016/j.msea. 2004.04.021

${ }^{2}$ G. Raab et al., Long-Length Ultrafine-Grained Titanium Rods Produced by ECAP-Conform, Materials Science Forum, 584-586 (2008), 80-85, doi:10.4028/www.scientific.net/MSF.584-586.80

${ }^{3}$ M. Duchek, T. Kubina, J. Hodek, J. Dlouhy, Development of the production of ultrafine-grained titanium with the conform equipment, Mater. Tehnol., 47 (2013) 4, 515-518

${ }^{4}$ T. Kubina, J. Dlouhy, M. Köver, J. Hodek, Preparation and thermal stability of ultra fine-grained commercially pure titanium wire, Proc. of Recent trends in structural materials COMAT 2012, Pilsen, 2012, [cited 2013-09-30]. Available from world Wide Web: http://www. comat.cz/files/proceedings/11/reports/1301.pdf

${ }^{5}$ E. A. Brandes, G. B. Brook, Smithels Metals Reference Book, 7th ed., Butterworth-Hernemann, Oxford 1992

${ }^{6}$ M. Hoseini et al., Thermal stability and annealing behaviour of ultrafine grained commercially pure titanium, Materials Science and Engineering A, 532 (2012), 58-63, doi:10.1016/j.msea.2011.10.062

${ }^{7}$ J. Gubicza et al., Microstructure of severely deformed metals determined by X-ray peak profile analysis, Journal of Alloys and Compounds, 378 (2004) 1/2, 248-252, doi:10.1016/j.jallcom.2003. 11.162 